\title{
STRATEGI PEMASARAN PADA UKM KERIPIK TEMPE SANAN MALANG
}

\author{
RAHMI YUNIARTI, ARIF RAHMAN, DAN MOCH.CHOIRI \\ Jurusan Teknik Industri, Fakultas Teknik, Universitas Brawijaya \\ Jalan MT. Haryono 167, Malang 65145, Jawa Timur \\ Laman: rahmi_yuniarti@ub.ac.id
}

\begin{abstract}
ABSTRAK
Usaha Kecil Menengah (UKM) memiliki peran yang besar pada perekonomian negara, baik dalam kontribusi terhadap Produksi Domestik Bruto maupun jumlah penyerapan tenaga kerja. Dalam usaha mengembangkan bisnisnya, UKM keripik tempe Sanan harus melakukan inovasi dan perbaikan untuk dapat bersaing dengan bisnis lainnya. Dengan adanya persaingan-persaingan dari berbagai merk keripik maka UKM keripik tempe Sanan harus melakukan peningkatan dalam hal penentuan strategi pemasaran. Analisis strategi yang dapat digunakan yaitu dengan mengunakan elemen pada bauran pemasaran. Hal ini yang mendorong perlunya untuk dilakukan penelitian mengenai faktor yang menjadi daya tarik program pemasaran, serta mengukur sejauh mana suatu kesatuan elemen bauran pemasaran dijalankan dalam strategi pemasaran yang ada. Sesudah mendapatkan informasi mengenai elemen bauran pemasaran dari hasil kuisioner yang diberikan kepada pihak produsen UKM keripik tempe, selanjutnya dilakukan analisis SWOT dan QSPM untuk menentukan strategi utama pemasaran. Dari hasil penelitian, strategi pemasaran yang harus dilakukan UKM keripik tempe Sanan Malang adalah melakukan diversified product dengan memproduksi berbagai jenis keripik, meluncurkan Brand variants sehingga konsumen memiliki banyak pilihan serta memproduksinya dalam komposisi berat keripik serta kemasan yang bervariasi, melakukan pengembangan jaringan agen penjualan untuk memperluas daerah penjualan, melakukan promosi melalui berbagai pameran dan acara-acara besar di propinsi Jawa Timur, menggencarkan promosi produk melalui iklan gratis dan media sosial yang tersedia.
\end{abstract}

Kata Kunci: strategi pemasaran, bauran pemasaran, analisis SWOT.

\begin{abstract}
Small and Medium Enterprises (SMEs) have a major role in the economy of country, both in contribution to the Gross Domestic Product and total employment. In order to develop its business, tempeh SME Sanan Chips has to create an innovation and conduct an improvement in order to be able to compete with other businesses. Due to existence of competition among the competitors with different brand of chips, so SME tempeh chips Sanan should improve properly the determination of marketing strategy. Strategy analysis can be conducted by using element of marketing mix. That triggers the necessity to conduct a research in terms of factors appealing marketing and measure how well a united element of marketing mix is performed according to the marketing strategy. After gaining information related to element of marketing mix from the questionnaire given to the SME tempe chips, then analysis is performed based on SWOT and QSMP to determine the major marketing strategy. According to the result, SME Sanan Chips should adopt the marketing strategy by: focusing on product diversity through producing various chips, launching a brand variant with a various pack and net weight in order to offer different choices to the consumers, developing an agent networks to expand the region of market sale, conduct promotion through exhibitions and major events in the Province of East Java, promoting the product intensively through a free advertisement and social media.
\end{abstract}

Keywords: marketing strategy, marketing mix , SWOT analysis. 


\section{PENDAHULUAN}

Salah satu penopang perekonomian bangsa Indonesia ialah Usaha Kecil dan Menengah (UKM). Industri pertanian, peternakan, kehutanan, dan perikanan merupakan industri dengan komposisi UKM terbesar dibandingkan dengan skala industri lainnya. UKM memiliki peran sangat besar dalam mendukung perekonomian negara sehingga pemerintah sebagai fasilitator harus memberikan perhatian yang lebih dalam pengelolaan UKM. Permasalahan yang masih menghambat masuknya produk UKM di gerai ritel modern, diantaranya masalah standar, continuity supply, packaging, dan desain (Meilani dan Simanjutak, 2012). Perhatian yang diberikan pemerintah dalam menyelesaikan permasalahan tersebut diharapkan mampu membuat UKM tetap bertahan dan berkembang sehingga semakin banyak memberikan manfaat yang berarti khususnya dalam penyerapan tenaga kerja dalam jumlah yang besar.

UKM keripik tempe Sanan merupakan salah satu UKM di kota Malang yang terkenal dengan produksi keripik tempe yang merupakan oleholeh khas Malang. Permintaan pangan terus meningkat karena merupakan kebutuhan dasar manusia sehingga berimbas terhadap peningkatan penawaran makanan. Oleh karena itu, bisnis di bidang makanan juga selalu meningkat dan berkembang dari waktu ke waktu (Rachmawati, 2011). Dengan adanya persaingan-persaingan dari berbagai merk keripik tempe maka UKM keripik tempe Sanan harus melakukan inovasi dan improvement dalam usaha mengembangkan pasarnya.

Penerapan konsep pemasaran modern berorientasi pasar atau pelanggan merupakan hal penting bagi keberhasilan pemasaran (Kotler, 2005). Perumusan strategi pemasaran harus memperhatikan persepsi pelanggan sehingga mampu menggambarkan kondisi yang mengarah kepada pemenuhan kebutuhan pelanggan. Teknik pemasaran yang dapat menciptakan permintaan pasti memiliki daya tarik tersendiri bagi konsumennya. Namun permasalahannya, daya tarik ini memiliki faktor yang bersifat tersembunyi dan seringkali sulit teridentifikasi dan terukur. Hal ini yang mendorong perlunya dilakukan penelitian sejauh mana suatu kesatuan elemen bauran pemasaran dijalankan dalam strategi pemasaran yang ada. Bauran pemasaran merupakan kombinasi dari berbagai elemen perusahaan yang dapat disesuaikan sedemikian rupa untuk menciptakan strategi pemasaran yang diinginkan. Tujuan penelitian ini adalah untuk mengetahui kondisi produsen keripik tempe Sanan dilihat dari perspektif bauran pemasaran, melakukan analisis Strengths, Weaknesses, Opportunities dan Threats (SWOT), dan memberikan rekomendasi berupa strategi pemasaran berdasarkan analisis SWOT dan Quantitative Strategic Planning Matrix (QSPM).

\section{METODE}

Bauran pemasaran dipergunakan untuk mengevaluasi pemasaran yang telah dilakukan oleh para pelaku UMKM keripik tempe Sanan Malang. Bauran pemasaran yang dipergunakan adalah Product, Place, Promotion dan Price. Kuisioner diberikan kepada para produsen keripik tempe Sanan untuk memberikan jawaban tentang kondisi UKM yang ada. Penyebaran kuesioner dan wawancara kepada pembuat/ produsen keripik tempe Sanan-Malang juga dilakukan untuk mendapatkan informasi sebagai dasar penyusunan matriks faktor internal dan eksternal. Selanjutnya dilakukan analisis SWOT dan penyusunan matriks SWOT. SWOT digunakan untuk menggambarkan secara jelas bagaimana peluang dan ancaman eksternal yang dihadapi perusahaan dapat disesuaikan dengan kekuatan dan kelemahan yang dimiliki (David, 2003). Selain itu, Matriks SWOT digunakan untuk mengetahui faktor- faktor strategis UKM di setiap kuadran Strength-Opportunities (SO), Strength-Threats (ST), Weakness-Opportunities (WO) dan Weakness- Threats (WT). Pemilihan strategi yang akan direkomendasikan ke UKM menggunakan Quantitative Strategic Planning Matrix (QSPM). 


\section{HASIL DAN PEMBAHASAN}

Pelaku Usaha Kecil dan Menengah (UKM) Keripik Tempe Sanan-Malang dapat dikelompokkan menjadi produsen dan penjual. Sebagian besar pelaku usaha yang berlokasi di dalam jalan kecil (gang) Sanan berperan sebagai produsen. Sedangkan pelaku usaha yang berlokasi strategis di Jalan Raya Sunandar Priyo Sudarmo Malang mayoritas berperan sebagai penjual. Banyak pelaku usaha yang merangkap selain sebagai produsen juga menjadi penjual.

Produk adalah strategi yang penting untuk dapat tetap kompetitif dalam menghadapi peningkatan maupun penurunan permintaan yang sering terjadi di dalam bisnis (Tjiptono, 2009). Semakin baik kualitas produk yang diberikan maka konsumen akan semakin berminat melakukan pembelian sehingga menjadi keharusan bagi UKM keripik tempe Sanan-Malang memberikan kualitas produk yang terbaik. Strategi pemasaran dari aspek produk yang dievaluasi meliputi diversified product, brand positioning, brand variants, shape variants, flavour variants, weight variants dan packaging variants seperti ditunjukkan pada Gambar 1.

Evaluasi pada diversified product untuk mengevaluasi apakah pelaku usaha lebih cenderung mengambil strategi fokus ke satu produk atau menerapkan strategi untuk memasarkan lebih dari satu product line. Berdasarkan hasil observasi seperti yang dideskripsikan Gambar 1 menunjukkan bahwa



Gambar 1. Marketing Mix pada Aspek Product
$30 \%$ melakukan pengembangan strategi diversified product yang tidak hanya fokus pada satu produk melainkan lebih dari satu product line. Strategi pemasaran dengan menawarkan atau memasarkan lebih dari satu product line adalah untuk melayani beberapa segmen pasar yang berbeda. Selain keripik tempe, beberapa pelaku usaha juga memasarkan produk keripik buah, ketela dan kentang yang juga merupakan produk unggulan Malang Raya.

Konsumen keripik tempe sebenarnya merupakan pasar monopolistik, karena antar produk mempunyai perbedaan yang tidak signifikan. Persaingan antar produsen dalam pasar monopolistik lebih pada bagaimana produsen mampu mempengaruhi konsumen untuk mengenali dan memilih produknya. Seringkali merek atau brand paling berperan dalam pasar monopolistik. Evaluasi bagaimana pelaku usaha keripik tempe Sanan sebagai produsen dalam mencitrakan produknya melalui merek dengan strategi brand positioning baru mencapai $70 \%$ seperti yang ditunjukkan pada Gambar 1. Perilaku konsumen dalam memilih produk seringkali diawali dengan mengevaluasi atau membandingkan dua atau lebih produk sejenis. Untuk melayani perilaku tersebut, maka produsen terkadang menawarkan lebih dari satu merek kepada konsumen melalui strategi brand variants. Berdasarkan Gambar 1, menunjukkan bahwa pelaku usaha keripik tempe Sanan hanya $20 \%$ yang menerapkan strategi brand variants. Keripik tempe Sanan mempunyai dua bentuk, yaitu lingkaran dan segi empat. Namun ternyata pelaku usaha keripik tempe Sanan yang mempergunakan kedua bentuk tersebut dalam strategi shape variants baru $60 \%$ seperti yang diilustrasikan pada Gambar 1.

Pelaku usaha sebaiknya menggunakan strategi weight variants untuk menawarkan produk dalam beberapa variasi ukuran atau berat produk untuk melayani perilaku konsumen terkait penggunaan produk dan tingkat konsumsinya. Pada Gambar 1 menunjukkan pelaku usaha keripik tempe Sanan hanya 50\% yang menerapkan strategi weight variants. Dalam industri pangan, 
perkembangan kemasan atau packaging cukup banyak dan bervariasi. Pelaku usaha keripik tempe Sanan masih belum banyak mengeksplor kemasan produk baik dari bahan maupun desain. Gambar 1 menunjukkan penerapan strategi packaging variants oleh pelaku usaha keripik tempe Sanan masih mencapai $10 \%$.

Penerapan strategi flavour variants yang dilakukan oleh pelaku usaha keripik tempe Sanan sudah baik, yaitu mencapai $80 \%$ seperti yang terlihat pada Gambar 2. Perkembangan produksi variasi bumbu baik instan maupun yang tradisional, dapat diserap dengan baik di usaha keripik tempe. Beberapa hanya mempergunakan lima rasa, namun ada yang menawarkan sepuluh rasa bahkan dua puluh rasa seperti yang ditunjukkan Gambar 2.

Strategi pemasaran dari aspek place yang dievaluasi meliputi owned channels, partner channels, delivery service dan market expansion seperti ditunjukkan pada Gambar 3. Pengembangan jaringan agen penjualan (sales channels) merupakan sebagian strategi pemasaran dari aspek place. Agen-agen penjualan tersebut dapat dimiliki sendiri atau juga dikelola outsourcing dengan sistem kemitraan dan perjanjian. Berdasarkan Gambar 3, 30\% pelaku usaha keripik tempe Sanan mengembangkan jaringan agen penjualan yang dimiliki sendiri (owned channels), bahkan beberapa pelaku mempunyai cabang yang tersebar di luar Jawa. Gambar 3 menunjukkan bahwa $60 \%$ pelaku usaha memanfaatkan marketing intermediaries

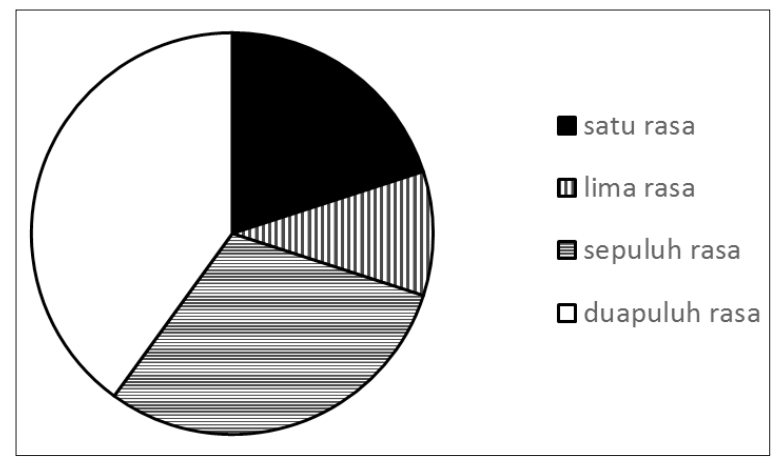

Gambar 2. Komposisi Flavour Variants dari Pelaku Usaha Keripik Tempe

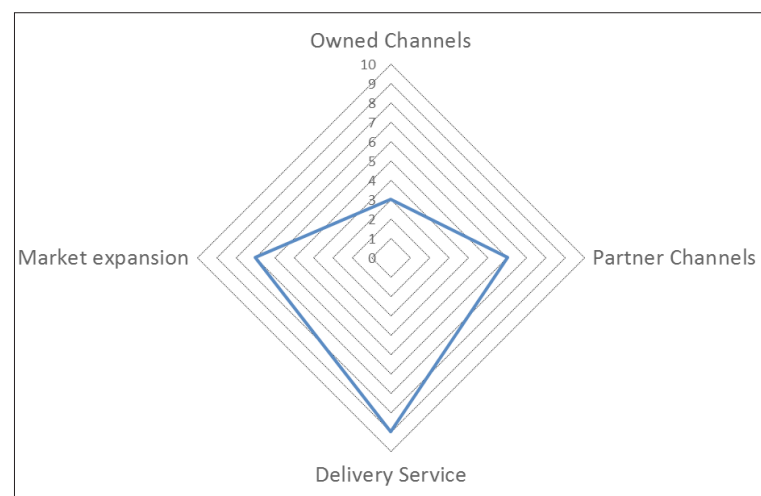

Gambar 3. Marketing Mix pada Aspek Place

untuk jaringan agen penjualan yang dikelola outsourcing dengan sistem kemitraan (partner channels) terutama tersebar di Malang Raya. Pelayanan yang diberikan oleh penjual keripik tempe dilakukan dengan mengirimkan produk keripik (delivery service) mencapai 90\%. Sementara itu, perluasan pangsa pasar yang dicapai adalah $60 \%$ pembeli berasal dari dalam dan luar Kota Malang.

Promosi merupakan kegiatan yang dilakukan untuk mengkomunikasikan keunggulan produk, membujuk dan mengingatkan konsumen untuk membeli produk. Persaingan antar produk di pasar, mendorong produsen melakukan promosi untuk menarik perhatian konsumen. Promosi dapat dilakukan melalui berbagai cara, antara lain: melalui promosi penjualan, publisitas umum, penjualan pribadi, dan periklanan. Promosi melalui media periklanan sangat efisien karena menggunakan biaya rendah dan mempunyai daya bujuk (persuasif) yang kuat. Selain itu, promosi melalui media periklanan sangat efektif karena dapat memberikan informasi yang jelas terhadap produk pada segmen tertentu. Iklan mengarahkan konsumen dalam menyuguhkan produk sehingga dapat diyakini untuk memenuhi kebutuhan pembeli (Pujiyanto, 2003). Pembeli keripik tempe Sanan mengenali dan memilih keripik tempe melalui informasi dari teman kerabat, mengenal produk dari pameran atau ulasan di media massa, dan sudah merupakan langganan. $60 \%$ dari produsen melakukan promosi melalui pameran seperti pameran di expo 
UMKM, Malang Tempoe Doeloe, dan pameran di beberapa kota.

Penentuan harga yang dilakukan oleh produsen kripik tempe, 70\% diantaranya dengan cara menambahkan laba yang diinginkan dengan ongkos produksi yang dikeluarkan. Layanan tambahan diberikan kepada konsumen yang membeli dalam jumlah besar. Hal ini dilakukan oleh $90 \%$ produsen dengan memberikan diskon, bonus, atau harga khusus pada konsumen.

\section{External Factor Evaluation (EFE)Matrix dan Internal Factor Evaluation (IFE) Matrix}

Berdasarkan hasil wawancara dan kuisioner kepada produsen keripik tempe Sanan dijadikan dasar dalam membuat External Factor Evaluation dengan memberikan bobot pada setiap faktor. Matriks EFE digunakan untuk mengevaluasi faktor-faktor eksternal UKM. Faktor eksternal berpengaruh secara langsung maupun tidak langsung terhadap perusahaan. Matriks EFE menganalisis hal yang berkaitan dengan sosial, teknologi, ekonomi, budaya dan politik. Tabel 1 adalah matrik EFE dari UKM keripik tempe Sanan.
Matriks IFE digunakan untuk mengetahui faktor-faktor internal perusahaan yang berkaitan dengan kekuatan dan kelemahan yang dianggap penting. Matriks IFE juga sebagai dasar untuk mengidentifikasi dan mengevaluasi hubungan antara bidang-bidang tersebut. Tabel 2 menunjukkan matrik IFE dari UKM keripik tempe Sanan.

\section{Analisis Strengths, Weakness, Opportunities, and Threats (SWOT)}

Analisis selanjutnya adalah analisis dengan menggunakan SWOT yang bertujuan untuk mengidentifikasi beberapa kemungkinan alternatif strategi yang secara intuitif dirasakan layak untuk dilaksanakan sehingga tidak semua alternatif strategi dimasukkan dalam analisa ini. Tabel 3 memperlihatkan strategi yang muncul dengan melihat SWOT yang dimiliki UKM keripik tempe Sanan Malang.

\section{Penentuan Alternatif Strategi Dengan Menggunakan Quantitative Strategic Planning Matrix (QSPM)}

Strategi-strategi yang telah ditentukan pada Tabel 3, perlu dianalisis kembali untuk

Tabel 2. Penilaian Skor untuk Faktor Kekuatan dan Kelemahan

\begin{tabular}{llllc}
\hline \multicolumn{1}{c}{ Faktor Strategi Internal } & \multirow{2}{*}{ Bobot } & \multirow{2}{*}{ Rating } & Skor \\
\cline { 3 - 5 } & & & & (BxR) \\
\hline Stok bahan baku selalu dibeli setiap hari & 0,044 & 3 & 0,132 \\
Bekerjasama dengan distributor dalam menyalurkan hasil produksi & 0,042 & 3,33 & 0,140 \\
Harga terjangkau bagi semua kalangan & 0,08 & 3,33 & 0,266 \\
Memberikan potongan harga bagi pembelian jumlah besar & 0,253 & 3 & 0,759 \\
Menampilkan merek produk dan informasi produk yang menarik & 0,14 & 3,67 & 0,514 \\
Memiliki varian rasa kripik tempe & 0,047 & 3,67 & 0,514 \\
Memiliki varian berat kemasan & 0,049 & 3,67 & 0,180 \\
Menggunakan iklan gratis dan twitter/media sosial gratis sebagai sarana akses & 0,167 & 2 & 0,334 \\
produksi & & & \\
Ready stock pada saat permintan tinggi sulit terpenuhi karena tidak & 0,032 & 2,33 & 0,075 \\
mampunya sumberdaya memenuhi permintaan konsumen & & & \\
Promosi hanya dilakukan didaerah sekitar Malang & 0,099 & 2 & 0,198 \\
Pembuatan produk hanya berfokus pada usaha kripik tempe & 0,043 & 3,5 & 0,151 \\
Total & 1 & & 3,263 \\
\hline
\end{tabular}


Tabel 3. Penentuan Strategi-Strategi Berdasarkan Analisis SWOT

\begin{tabular}{|c|c|c|}
\hline & $\begin{array}{l}\text { Strengths } \\
\text { 1. Stok bahan baku selalu dibeli } \\
\text { setiap hari } \\
\text { 2. Bekerja s a m a dengan } \\
\text { distributor dalam menyalurkan } \\
\text { hasil produksi } \\
\text { 3. Harga terjangkau bagi semua } \\
\text { kalangan } \\
\text { 4. Memberikan potongan harga } \\
\text { bagi pembelian jumlah besar } \\
\text { 5. Menampilkan merek produk } \\
\text { dan informasi produk yang } \\
\text { menarik } \\
\text { 6. Memiliki varian rasa keripik } \\
\text { tempe } \\
\text { 7. Memiliki varian berat } \\
\text { kemasan } \\
\text { 8. Menggunakan iklan gratis } \\
\text { dan twitter/media sosial } \\
\text { gratis sebagai sarana akses } \\
\text { produksi }\end{array}$ & $\begin{array}{l}\text { Weaknesses } \\
\text { 1. Ready stock pada saat } \\
\text { permintan tinggi sulit } \\
\text { terpenuhi karena tidak } \\
\text { mampunya sumberdaya } \\
\text { memenuhi permintaan } \\
\text { konsumen } \\
\text { 2. Promosi hanya dilakukan d } \\
\text { idaerah sekitar Malang } \\
\text { 3. Pembuatan produk hanya } \\
\text { berfokus pada usaha keripik } \\
\text { tempe }\end{array}$ \\
\hline $\begin{array}{l}\text { Opportunities } \\
\text { 1. Lingkungan produksi yang } \\
\text { sama menjadikan tempat } \\
\text { ini dikenal oleh masyarakat } \\
\text { sehingga peluang untuk } \\
\text { mendapatkan pelanggan baru } \\
\text { juga tinggi. } \\
\text { 2. Perkumpulan UMKM Malang } \\
\text { mengadakan expo untuk } \\
\text { membantu promosi usaha } \\
\text { industri Sanan. } \\
\text { 3. Penggunaan layanan iklan } \\
\text { gratis dan media sosial } \\
\text { seperti twitter dan blogspot } \\
\text { mempermudah produsen } \\
\text { dalam mempromosikan } \\
\text { produknya. }\end{array}$ & $\begin{array}{l}\text { - S1 O1: Menjadi produsen } \\
\text { pembuatan tempe mentah } \\
\text { yang menyediakan kebutuhan } \\
\text { produsen tempe lainnya dan } \\
\text { juga pembuatan tempe yang } \\
\text { telah diolah. } \\
\text { - S8 O3: Menggencarkan } \\
\text { promosi produk melalui iklan } \\
\text { gratis dan media sosial yang } \\
\text { tersedia } \\
\text { - S2 02: Menjalin kerjasama } \\
\text { dengan mitra kerja dalam } \\
\text { mengembangkan pasar dan } \\
\text { menarik investor untuk } \\
\text { pengembangan usaha }\end{array}$ & $\begin{array}{l}\text { - W1 O1: Menjalin kerjasama } \\
\text { dengan penjual sekitar } \\
\text { untuk memenuhi kuantitas } \\
\text { permintaan dari konsumen } \\
\text { - W2 O3: Melakukan promosi } \\
\text { dengan memanfaatkan } \\
\text { media internet untuk } \\
\text { menyebarluaskan promosi } \\
\text { produk } \\
\text { - W3 O1O4: Memproduksi } \\
\text { produk baru selain keripik } \\
\text { tempe }\end{array}$ \\
\hline $\begin{array}{l}\text { Threats } \\
\text { 1. Naiknya harga bahan baku } \\
\text { 2. Kesulitan dalam mencari } \\
\text { tenaga kerja } \\
\text { 3. Lingk ungan khusus } \\
\text { penghasil produk yang sama } \\
\text { menyebabkan terjadinya pasar } \\
\text { persaingan sempurna. }\end{array}$ & $\begin{array}{l}\text { - S6 T5: memperbaharui } \\
\text { teknologi yang sudah ada } \\
\text { dengan teknologi otomatis } \\
\text { - S4 T7: memberikan promo- } \\
\text { promo baru atau potongan } \\
\text { harga untuk menjaring } \\
\text { pelanggan baru. } \\
\text { - S6 T3: Melakukan inovasi } \\
\text { produk dan kemasan }\end{array}$ & $\begin{array}{l}\text { W1 T3T8: Menjalin kerjasama } \\
\text { dengan setiap kompetitor yang } \\
\text { ada dalam merespon kondisi } \\
\text { ketidak sanggupan memenuhi } \\
\text { permintaan dari konsumen } \\
\text { yang sangat tinggi } \\
\text { - W1 T1: Melakukan kontrak } \\
\text { pembelian dengan pemasok } \\
\text { bahan baku (kedelai) }\end{array}$ \\
\hline
\end{tabular}


4. Kebijakan pemerintah seperti adanya pajak $10 \%$ bagi UMKM menjadikan salah satu kendala dalam meningkatkan peluang usaha.

5. Produsen industri sanan masih menggunakan semi teknologi dengan bantuan manusia sebagai penghasil tenaga. Seperti pengepakan menggunakan lilin, dan penggorengan masih menggunakan metode seharisehari.

6. Penggunaan teknologi informasi seperti pembuatan blog kurang diminati, karena pada pembuatan blog resmi, setiap bulan dikenakan biaya.

7. Persaingan yang ketat dengan produsen lain dikarenakan persaingan harga jual yang berubah dapat mempengaruhi tingkat pembelian.
S1 T2: Melakukan berdasarkan harga awal yang penambahan tenaga kerja disepakati untuk membuat tempe mentah dan produksi keripik tempe menentukan alternatif strategi mana yang harus diprioritaskan untuk dijalankan. Hal ini dilakukan untuk penghematan biaya dalam melakukan inovasi peningkatan pangsa pasar. Tabel 4 merupakan matriks QSPM untuk penentuan strategi yang dipilih. Dari hasil QSPM didapatkan urutan strategi yang direkomendasikan untuk diaplikasikan pada UKM keripik tempe Sanan-Malang seperti ditunjukkan pada Tabel 5 .

Berdasarkan Tabel 5 di atas, strategi yang dipilih yaitu strategi menggencarkan promosi produk melalui iklan gratis dan media sosial yang tersedia. Hal ini bisa dilakukan dengan menggunakan fasilitas internet yang bisa diakses secara cuma-cuma. Pembuatan ecommerce disarankan untuk memperkenalkan produk keripik ke masyarakat luas, dalam dan luar negeri. Selain itu, dengan menggunakan $e$ - commerce dapat meningkatkan penjualan dari produk keripik.

\section{SIMPULAN}

UKM keripik tempe Sanan perlu melakukan diversified product dengan memproduksi berbagai jenis keripik dilihat dari aspek product. Selain itu, UKM perlu meluncurkan brand variants sehingga konsumen memiliki banyak pilihan serta memproduksinya dalam komposisi berat keripik serta kemasan yang bervariasi. Sementara itu dari aspek place, agen penjualan UKM kurang tersebar luas sehingga diperlukan pengembangan jaringan agen penjualan untuk memperluas daerah penjualan. Selanjutnya dari aspek promotion, UKM perlu melakukan promosi melalui berbagai pameran dan acara-acara besar di propinsi Jawa Timur. Terakhir dari aspek price, penentuan harga ditentukan oleh UKM serta 


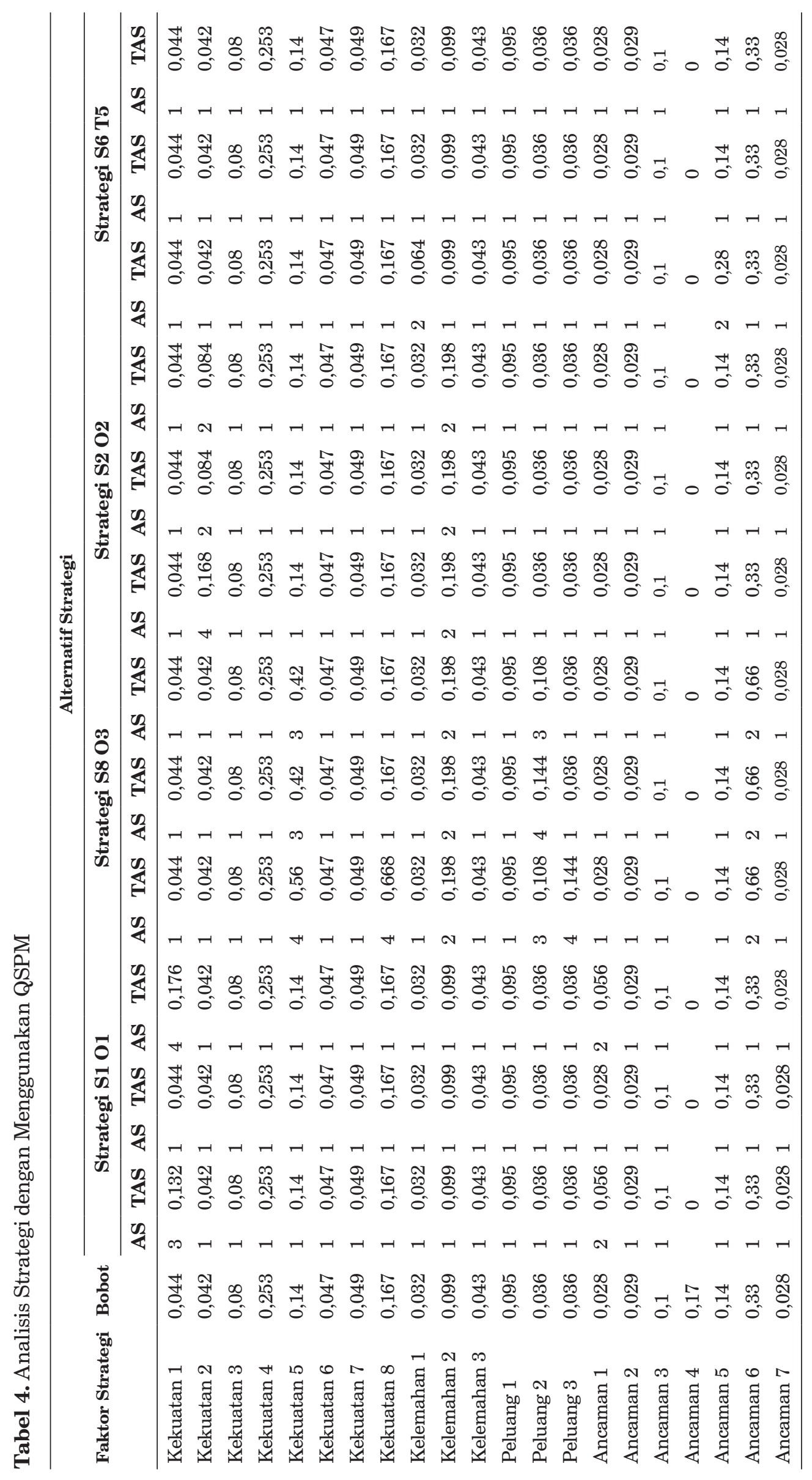




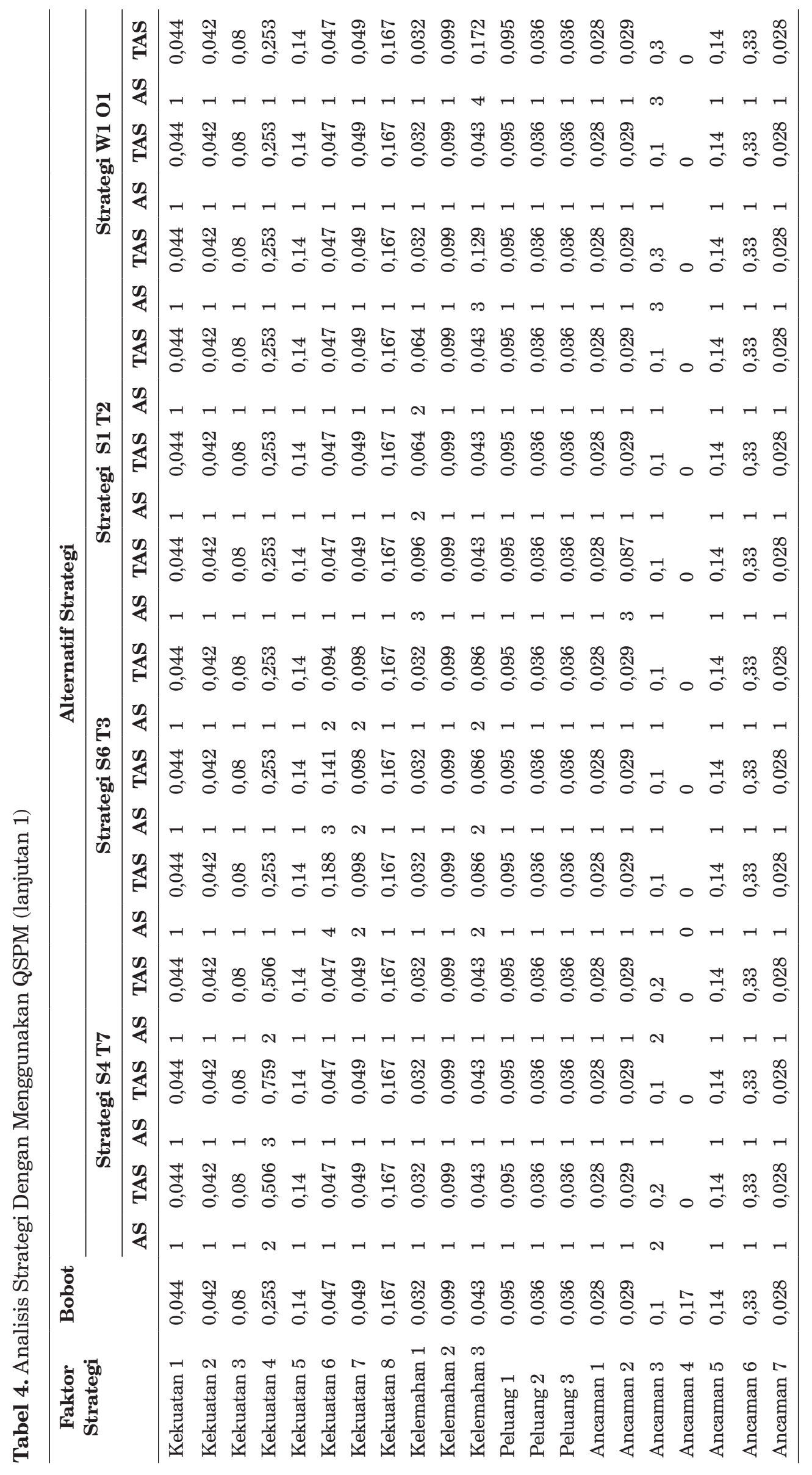




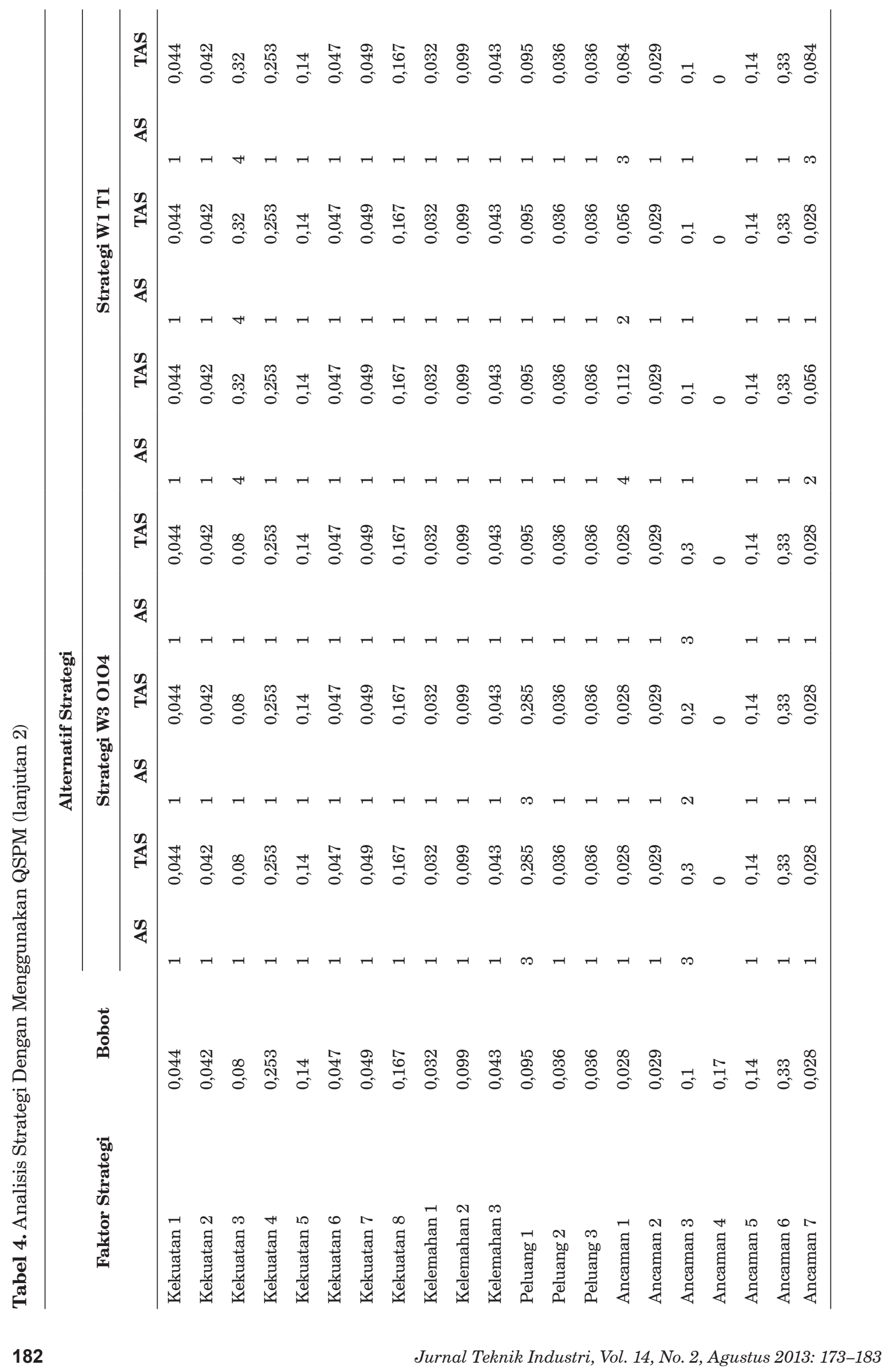


Tabel 5. Prioritas Strategi yang Direkomendasikan pada UKM Keripik Tempe Sanan

\begin{tabular}{|c|c|c|c|}
\hline Strategi & Keterangan & Rata-Rata & Rank \\
\hline S8 O3 & $\begin{array}{l}\text { Menggencarkan promosi produk melalui iklan gratis dan media sosial } \\
\text { yang tersedia }\end{array}$ & 2,861 & 1 \\
\hline $\mathrm{S} 4 \mathrm{~T} 7$ & $\begin{array}{l}\text { Memberikan promo-promo baru atau potongan harga untuk menjaring } \\
\text { pelanggan baru. }\end{array}$ & 2,222 & 2 \\
\hline $\mathrm{W} 1 \mathrm{~T} 1$ & $\begin{array}{l}\text { Melakukan kontrak pembelian dengan pemasok bahan baku (kedelai) } \\
\text { berdasarkan harga awal yang disepakati }\end{array}$ & 2,142 & 3 \\
\hline W3 0104 & Memproduksi produk baru selain keripik tempe & 2,111 & 4 \\
\hline $\mathrm{W} 1 \mathrm{O} 1$ & $\begin{array}{l}\text { Menjalin kerjasama dengan penjual sekitar untuk memenuhi kuantitas } \\
\text { permintaan dari konsumen }\end{array}$ & 2,023 & 5 \\
\hline S6 T3 & Melakukan inovasi produk dan kemasan & 2,004 & 6 \\
\hline S2 02 & $\begin{array}{l}\text { Menjalin kerjasama dengan mitra kerja dalam mengembangkan pasar } \\
\text { dan menarik investor untuk pengembangan usaha }\end{array}$ & 1,987 & 7 \\
\hline S1 01 & $\begin{array}{l}\text { Menjadi produsen pembuatan tempe mentah yang menyediakan } \\
\text { kebutuhan produsen tempe lainnya dan pembuatan tempe yang telah } \\
\text { diolah }\end{array}$ & 1,91 & 8 \\
\hline $\mathrm{S} 1 \mathrm{~T} 2$ & $\begin{array}{l}\text { Melakukan penambahan tenaga kerja untuk membuat tempe mentah } \\
\text { dan produksi keripik tempe }\end{array}$ & 1,88 & 9 \\
\hline $\mathrm{S} 6 \mathrm{~T} 5$ & $\begin{array}{l}\text { Memperbaharui teknologi yang sudah ada dengan teknologi } \\
\text { otomatis }\end{array}$ & 1,875 & 10 \\
\hline
\end{tabular}

memberikan harga khusus kepada konsumen besar. Prioritas strategi yang diimplementasikan bagi UKM adalah menggencarkan promosi produk melalui iklan gratis dan media sosial yang tersedia.

\section{DAFTAR PUSTAKA}

David, F.R., 2003. Manajemen Strategi. Jakarta: Pearson Education Asia Pte.Ltd dan PT.Prehallindo.

Kotler, P., 2005. Marketing Management: Analysis, Planning, Implementation, and Control. Englewood Cliffs, NJ: PrenticeHall, Inc.
Meilani, Y. F dan Simanjutak, S., 2012. Faktor yang Mempengaruhi Minat Beli Produk Makanan dan Minuman Usaha Kecil Menengah Kabupaten Tangerang, Jurnal Manajemen dan Kewirausahaan, 14 (2), 162-170.

Pujiyanto. 2003. Strategi Pemasaran Produk melalui Media Periklanan, NIRMANA, 5 (1), 960.

Rachmawati, R., 2011. Peranan Bauran Pemasaran (Marketing Mix) terhadap Peningkatan Penjualan (Sebuah Kajian Terhadap Bisnis Restoran), Jurnal Kompetensi Teknik, 2 (2), 143150.

Tjiptono, F., 2009. Service Marketing Esensi dan Aplikasi, Malang: Bayu Media. 